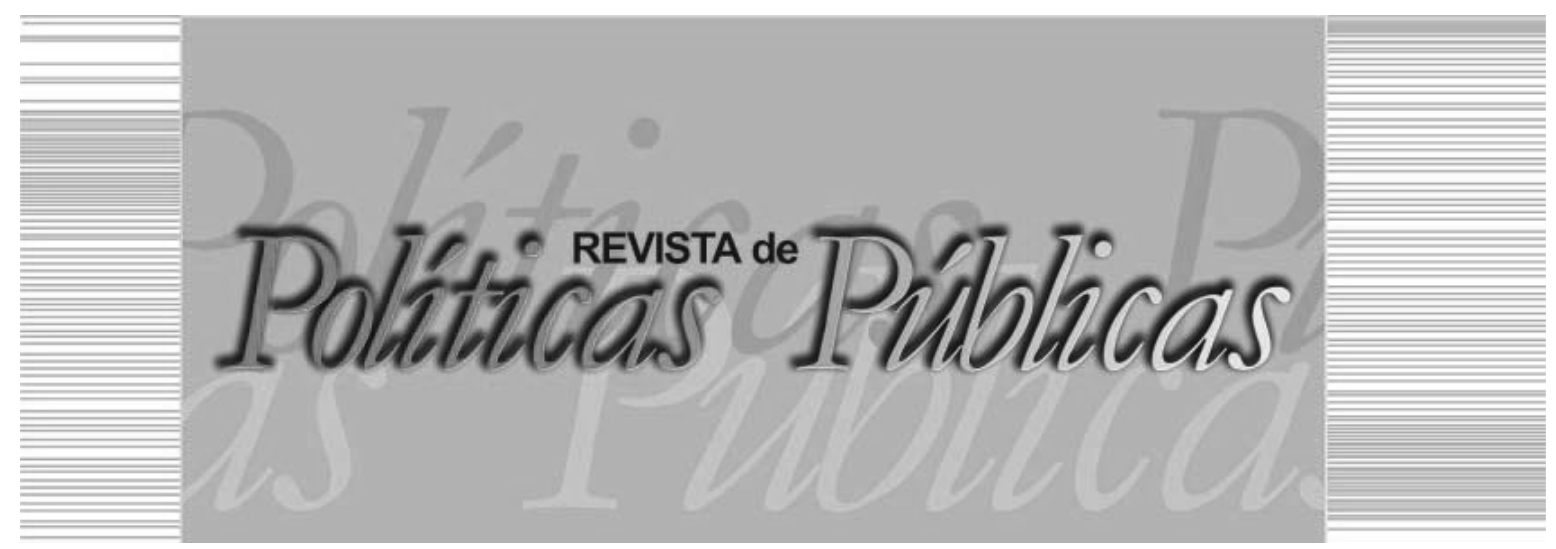

\title{
POLITICAS SOCIAIS HABITACIONAIS RURAIS NO SUL DE SANTA CATARINA ${ }^{7}$
}

\author{
Juliane Possamai Gonçalves ${ }^{1}$ \\ Miguelangelo Gianezini ${ }^{2}$ \\ Dimas de Oliveira Estevam ${ }^{3}$
}

\section{Resumo}

O meio rural no Brasil mudou com o êxodo do campo, a industrialização e a urbanização das últimas décadas. E no início deste século ganhou elementos que o tornaram heterogêneo, demandando políticas específicas. Partindo desse contexto, este artigo realiza uma pesquisa interdisciplinar com o objetivo de analisar as políticas públicas sociais habitacionais rurais, tendo como locus municípios do Sul catarinense, escolhidos pela experiência de implementação das mesmas com apoio do sindicato dos trabalhadores rurais. Para este estudo de caso, adota pesquisa descritiva, exploratória e aplicada, com revisão de literatura, levantamento documental e pesquisa de campo. Para a coleta de dados, opta pela técnica de observação, em contato com agentes sociais locais e beneficiários. Os resultados são apresentados e discutidos qualitativamente. Considera, ainda, que o tema teve pouca atenção dos policy makers, uma vez que a moradia era vista como adjacência da propriedade rural. Contudo, recentes políticas

\footnotetext{
1 Economista, Mestra em Desenvolvimento Socioeconômico pela Universidade do Extremo Sul Catarinense (UNESC). E-mail: july_pop1@hotmail.com / Endereço: Universidade do Extremo Sul Catarinense - UNESC: Av. Universitária, nº 1105 - Bairro Universitário. Criciúma/SC. CEP: 88806-000

2 Cientista Social e Administrador, Doutor em Agronegócios pela Universidade Federal do Rio Grande do Sul (UFGRS), Professor Permanente do Programa de Pós-Graduação em Desenvolvimento Socioeconômico (PPGDS/UNESC). E-mail: mgianezini@outlook. com

3 Economista, Doutor em Sociologia Política pela Universidade Federal de Santa Catarina (UFSC), Professor Permanente do Programa de Pós-Graduação em Desenvolvimento Socioeconômico (PPGDS/UNESC). E-mail: doe@unesc.net
} 
têm alterado este quadro, incluindo a região estudada, onde sindicatos e demais entidades sociais contribuem para o aprimoramento desse processo e da gestão do desenvolvimento social.

Palavras chave: Políticas Públicas, gestão social, Programa Nacional de Habitação Rural, desenvolvimento rural.

\title{
RURAL HOUSING SOCIAL POLICIES AT THE SOUTHERN OF SANTA CATARINA STATE, BRAZIL
}

\begin{abstract}
The rural environment in Brazil has changed with the rural exodus, the industrialization and the urbanization that occurred in recent decades. At the beginning of this century this landscape became more heterogeneous, demanding specific policies to deal with new challenges. Based on this context, an interdisciplinary research was conducted in order to analyze rural housing social policies at municipalities in southern Santa Catarina State (Brazil), chosen for the experience of implementing social policies with the support of the rural workers' union. For this case study, a descriptive, exploratory and applied research was undertaken, with literature review, documentary survey and field research. For the data collection, we opted for the observation technique, in contact with local social agents and beneficiaries. The results were presented and discussed qualitatively. It is considered that housing issue had little attention of the policy makers, since the dwelling was seen as an adjacency of the rural property. However, recent policies have altered this framework, including the region studied, where unions and other social entities contribute to the improvement of this process and the management of social development.

Key words: Public policies, public housing policies, Rural Housing National Program, rural development.

Recebido em: Aprovado em:
\end{abstract}

\section{INTRODUÇÃO}

Nos primórdios da organização social, os povos buscaram espaços para abrigo e convivência em concomitância com o surgimento das primeiras famílias e fixação territorial para atividades agropecuárias rudimentares. Ao longo da história, este espaço de abrigo e convivência foi construído com diversos tipos de material, em vários formatos arquitetônicos e recebeu distintas nomenclaturas (casa, moradia, residência, habitat artificial, lar).

A edificação de habitações contribuiu para a formação das cidades e desenvolvimento de atividades socioeconômicas em todo o mundo. Nesse processo histórico, muitos povos experimentaram 
êxodos do campo para a cidade (Egito Antigo, Roma Imperial, Indochina, Europa Medieval e Renascentista e Península Ibérica das Grandes Navegações). E o melhor exemplo disso se deu com o advento da Revolução Industrial na Inglaterra, onde a necessidade premente de urbanização e moradia criaram problemas e situações complexas para a sociedade da época. (ENGELS, 1935; MENDRAS, 1984; BRESCIANI, 1994). Assim, daquele momento em diante a questão da habitação no meio urbano passa a ser uma preocupação latente, tanto para governantes, que precisam lidar com um novo cenário, quanto para estudiosos, que voltam a sua atenção para esse fenômeno e seus desdobramentos (crescimento populacional, saúde coletiva, mobilidade, segurança pública e outros).

Essa condição levou à necessidade de planejamento urbano e de implementação de políticas públicas específicas para esse contingente populacional, tanto nos países hoje considerados desenvolvidos, quanto nos países em desenvolvimento que experimentaram momentos de esvaziamento do campo, como é o caso do Brasil. Observa-se o êxodo rural brasileiro como um fenômeno que se acentuou com o processo de industrialização e a consequente urbanização. Tal fenômeno se concentrou nas últimas décadas do século XX e neste início de século, quando ganhou contornos heterogêneos. Portanto, cada período histórico possui demandas socioeconômicas que precisam ser atendidas pelo poder público, iniciativa privada ou terceiro setor, seja em âmbito nacional, estadual ou regional, com diferentes características. (GONÇALVES; GIANEZINI; ESTEVAM, 2015b).

Tendo em vista esta breve retrospectiva e contextualização, percebeu-se a necessidade de compreender as iniciativas habitacionais em espaços com predomínio do ambiente rural. Assim, na perspectiva de contribuir para o estudo das Políticas em habitação, sob uma ótica interdisciplinar, este artigo teve como objetivo analisar as políticas públicas sociais habitacionais rurais (com ênfase na gestão social e no desenvolvimento rural), implementadas no ambiente do extremo sul do estado de Santa Catarina, representadas pela experiência em dois municípios.

\section{REVISÃO DE LITERATURA}

No último século a questão habitacional foi amplamente estudada e debatida no meio urbano, bem como seus impactos e desafios. Entretanto, cabe mencionar que durante este período, o tema 
foi pouco explorado no meio rural, uma vez que a moradia era considerada uma adjacência da propriedade rural e, portanto, um espaço organizado pelos proprietários.

Essa situação é constatada em algumas áreas do conhecimento, com destaque para as ciências sociais. Mendras (1984) ponderou que as ciências sociais, em especial no século XIX, careceram de um olhar que compreendesse as coisas rústicas. Para o autor, as ciências sociais focaram na análise da economia industrial e da sociedade urbana (incluindo a classe operária, a eficácia da empresa capitalista e o instrumento monetário) e se desinteressaram por um sistema social que funciona sem assalariados, nem empresários, nem moeda e que, no entanto, permanecia majoritário no Ocidente. (MENDRAS, 1984).

Ao aplicar essa reflexão à condição da habitação brasileira, observa-se que, além do esquecimento do ambiente rural, há uma dissociação histórica entre a moradia e os demais serviços públicos. (COSTA, 1995). No ambiente urbano também há problemas, como apontado por Maricato (2001), para quem a oferta de moradia no país, de maneira geral, restringe-se à construção de casas e apartamentos, sem articulação com o meio urbano e sua inserção no contexto das cidades. Em complemento, Denaldi, Leitão e Akaishi (2001) traçaram uma retrospectiva histórica das políticas habitacionais no Brasil, demonstrando a ausência do Estado no planejamento do setor.

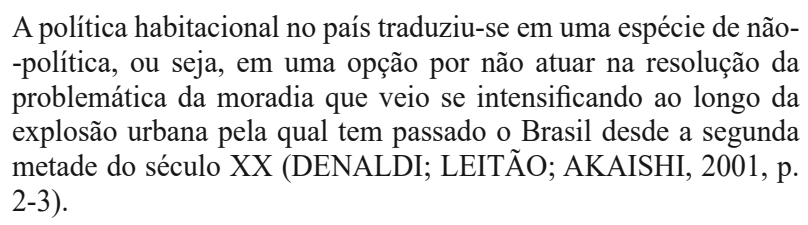
-política, ou seja, em uma opção por não atuar na resolução da problemática da moradia que veio se intensificando ao longo da explosão urbana pela qual tem passado o Brasil desde a segunda metade do século XX (DENALDI; LEITÃO; AKAISHI, 2001, p. 2-3).

Tais questões ficaram mais evidentes no bojo de redemocratização do Brasil. Há elementos representativos do período militar que foram transformados ou deixaram de existir. E dentre esses, um dos mais simbólicos foi a extinção do Banco Nacional de Habitação (BNH) em 1986 (AZEVEDO,1988). Desde então as políticas voltadas ao enfrentamento da problemática habitacional foram descontínuas, alternando programas baseados na iniciativa dos governos locais, do setor empresarial ou do setor cooperativo (CARDOSO; ARAGÃO; ARAUJO, 2011). 
Daquele momento em diante foram promovidas novas ações, que resultaram nas bases para as políticas públicas no Brasil e, por consequência, para as políticas sociais habitacionais atuais em diversos estados brasileiros, em especial, naqueles onde houve processos de urbanização, associados à diversificação socioeconômica, como é o caso de Santa Catarina.

E nas últimas décadas, municípios como os localizados no Sul Catarinense têm buscado diversificar suas matrizes produtivas, integrando outras atividades a uma nova realidade do desenvolvimento socioeconômico do estado (GONÇALVES; GIANEZINI, 2014). Isto porque são impactados pela duplicação do Eixo-Sul da BR-101, em um processo - com resultado econômico que proporciona prosperidade, mas também ocasiona problemas - que tem modificado o panorama da região, conhecida até pouco tempo apenas pela exploração mineral.

\subsection{Desenvolvimento Socioeconômico, Gestão Social e Habitação}

$\mathrm{O}$ conceito de desenvolvimento tem recebido diversas interpretações e abordagens, algumas por vezes confusas ou até mesmo equivocadas. Neste estudo, adotou-se o entendimento de Celso Furtado como balizador para buscas das ações habitacionais rurais contribuintes para o desenvolvimento. Nas palavras do autor:

O conceito de desenvolvimento tem sido utilizado, com referência
à história contemporânea, em dois sentidos distintos. O primeiro
diz a respeito à evolução de um sistema social de produção à me-
dida que este, mediante a acumulação e o progresso das técnicas,
torna-se mais eficaz, ou seja, eleva a produtividade do conjunto de
sua força de trabalho [...]. O segundo sentido em que faz referência
ao conceito de desenvolvimento relaciona-se com grau de satisfa-
ção das necessidades humanas (FURTADO, 2000, p. 21).

Por conseguinte, o desenvolvimento tem que ser pensado almejando um aumento da efetividade das políticas sociais, sempre tendo em vista as necessidades do povo. Furtado ainda salienta: "[...] a ideia de desenvolvimento possui pelo menos três dimensões: a do incremento da eficácia do sistema social de produção, a satisfação de necessidades elementares da população e a da consecução de objetivos a que almejam grupos dominantes." (FURTADO, 2000, p. 22, grifo nosso). Dessa forma, a questão da habitação encontra-se 
na segunda dimensão mencionada, qual seja, a de atender a uma das necessidades elementares da população.

Contudo, o que parece óbvio e de resolução objetiva, teve ao longo da história (e ainda tem) muitas nuances. De fato, o problema da questão habitacional já vem ocorrendo há muito tempo, não só no Brasil. Friedrich Engels (1935) já havia constatado esse problema ainda na Inglaterra do século XIX, berço da revolução industrial, que requeria habitação urbana para os milhares de trabalhadores das fábricas. Nas palavras da época do autor " [...] constrói-se tão barato na Inglaterra que as casas estremecem quando passa uma carroça e todos os dias há algumas que desabam.” (ENGELS, 1935, p. 62-63).

A resolução dessas necessidades na Inglaterra de hoje e em demais países desenvolvidos é uma realidade, mas na atualidade brasileira essa questão ainda é latente, propiciando que estudos e o conhecimento produzido sobre a temática tenham seu foco nas mudanças políticas ocorridas nas últimas décadas, o que torna imprescindível o planejamento das políticas públicas e sociais. (PARENTE, 2001).

A necessidade de tal planejamento e, em especial, as ações resultantes do mesmo, vão ao encontro do aprimoramento da Gestão Social no Brasil. Cançado e outros (2008) e Cançado (2011) organizaram estudos e promoveram ampla revisão de literatura acerca dos fundamentos teóricos desse tipo de gestão. Dentre seus resultados, constam estudos agrupados em uma categoria de análise denominada Gestão do Desenvolvimento Social, que abarca textos que entendem a Gestão Social como

[...] a gestão de Projetos ou Programas Sociais, Políticas Públicas, Políticas Públicas Sociais (conduzidos ou não pelo Estado) e dos aspectos sociais da Administração Pública. Esta categoria de análise contempla também textos que apresentam a Gestão Social como Gestão Social do desenvolvimento, gestão de redes e interorganizações. (CANÇADO, 2011, p. 125) ${ }^{2}$.

Por conseguinte, Silva Jr., Gonçalves e Calou (2008) afirmam que o termo Gestão Social tem recebido interpretações variadas. Dentre estas, a que foi utilizada neste estudo está na publicação de Bernardo Kliksberg (1994) A gerência social, uma gerência diferente na qual Gestão Social é entendida como gestão de políticas públicas sociais. Outro estudioso com significativa contribuição para a compreensão da Gestão Social é Fernando Tenório. De forma di- 
nâmica, o autor explica que no processo de Gestão Social há uma promessa de consenso racional, na qual a relação não se dá entre o indivíduo e a sua percepção de mundo, mas sim por meio de um acordo alcançado com discussão crítica e apreciação intersubjetiva. (TENÓRIO, 2008).

\subsection{Políticas Públicas e Políticas Sociais Habitacionais}

Esta seção alude à delimitação da temática de estudo, uma vez que busca apresentar uma caracterização, de maneira geral, das políticas públicas, das políticas sociais, setoriais e de forma específica, das políticas sociais habitacionais. Muitos são os conceitos e entendimentos deste encadeamento, e, portanto, optou-se pela elaboração de um esquema-síntese (Figura 1) das definições que balizaram o estudo e a análise dos resultados.

Do ponto de vista prático, para compreender tais políticas e, em especial, seus impactos na sociedade, são fundamentais os estudos e pesquisas que investiguem a tomada de decisão (e de posição) de agentes governamentais e não governamentais perante as questões sociais. Há também o entendimento das diversas formas de organização da sociedade civil e sua relação com o setor público. Essas definições contribuem para a compreensão geral e apontam para a necessidade de práticas com planejamento, monitoramento bons resultados.

Figura 1 - Estudos em políticas públicas/setoriais/sociais balizadoras do estudo

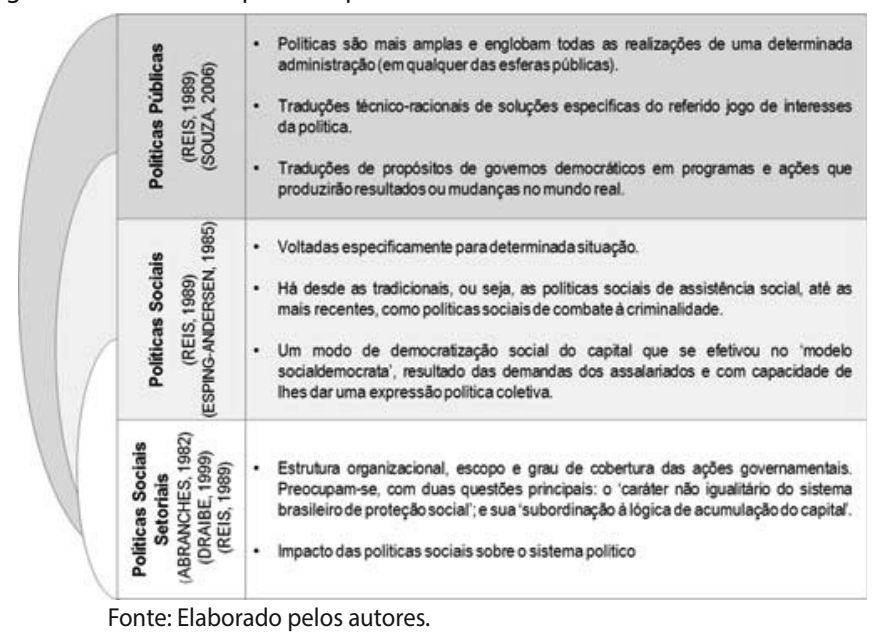


Do ponto de vista governamental, são as políticas públicas que permitem ao Estado, partindo de demandas sociais, formular e implementar ações práticas (GIANEZINI; BARRETTO; VIEIRA, 2015). Os mesmos autores ressaltam, em seu estudo sobre o processo de criação de políticas públicas, que se uma política não dispõe de recursos para implementação, não representará nada mais do que uma boa ideia ou intenção. Esse é o típico caso de algumas políticas habitacionais brasileiras (governamentais ou não) que não dispuseram de linhas de crédito adequadas para seus beneficiários.

Por conseguinte, na seara das políticas públicas sociais, Souza Santos (2002) contribui com uma perspectiva sistêmica, na qual se faz mister o papel da habitação. Segundo ele, para implementar uma política social "“...] é indispensável eleger um programa estruturador que leve em conta as condições socioeconômicas do Brasil. E não é o programa de educação que possui essas condições transformadoras, mas sim, o programa de habitação." (SOUZA SANTOS, 2002, p. 948-949).

Desse modo, as políticas sociais habitacionais poderiam ser de fato caracterizadas como práticas bem-sucedidas, ações, iniciativas e projetos, no âmbito local, que têm resultado em melhoria tangível e mensurável das condições de vida e do habitat da população, contribuindo para a redução de seu custo e a melhoria da qualidade de vida das pessoas. (BONDUKI, 1997).

Ao término dessa seção, cabe mencionar dois avanços sociais no panorama habitacional brasileiro deste início de século. O primeiro diz respeito à instituição do Sistema Nacional de Habitação de Interesse Social (SNHIS), trazendo para a responsabilidade do Estado, a promoção de moradia para os segmentos pauperizados da classe trabalhadora (ABREU, 2016), com destaque para a institucionalização de programas financiados por recursos do Fundo Nacional de Habitação de Interesse Social (FNHIS). E o segundo - resultante de movimentos da Nova Economia Institucional - no qual há políticas públicas habitacionais que passam a ser construídas socialmente, sendo formuladas em conjunto com organizações sociais, além de ações e projetos independentes, implementados por organizações não governamentais ${ }^{3}$, cooperativas habitacionais ${ }^{4} \mathrm{e}$ outras entidades. 


\subsection{Desenvolvimento Rural e Habitação}

Em âmbito nacional, Schneider (2010) caracteriza o contexto de surgimento do debate sobre o desenvolvimento rural no Brasil, descrevendo elementos das mudanças políticas, sociais e econômicas que estão na sua raiz. O autor pontua as perspectivas que orientam os pesquisadores na interpretação dos processos de mudança social que estão ocorrendo no espaço rural. Em seu estudo, há inclusive uma seção dedicada ao chamado novo rural brasileiro, preconizado por José Graziano da Silva (1999), que trata do crescimento das atividades não-agrícolas resultantes do emprego de habitantes rurais no meio urbano e políticas compensatórias.

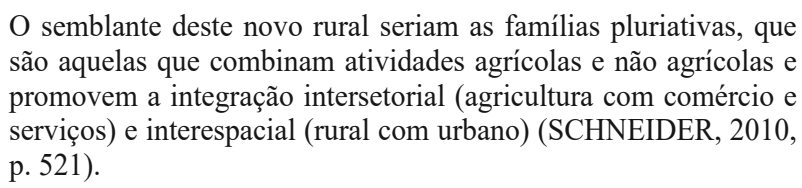

O semblante deste novo rural seriam as famílias pluriativas, que são aquelas que combinam atividades agrícolas e não agrícolas e promovem a integração intersetorial (agricultura com comércio e serviços) e interespacial (rural com urbano) (SCHNEIDER, 2010, p. 521).

Contudo, essas famílias pluriativas estão muitas vezes inseridas em um ambiente no qual falta estrutura, ou os bens e serviços são escassos. Ademais, quando apresentada esta condição para pessoas do meio urbano, elas facilmente remetem o mesmo (meio rural) para um local isolado, sem escola, hospital, energia elétrica, estradas precárias, etc. Esse cenário tem se modificado por meio de políticas públicas e o assunto é amplamente debatido, sendo tema de várias discussões pelo mundo. Para Schneider (2010, p. 522, grifo nosso):

Este conjunto de políticas sociais e compensatórias, destinadas a amplos contingentes da população rural que vivem em condições de pobreza e vulnerabilidade social (particularmente na região semiárida do Nordeste), deveria ser somado às políticas para o novo rural brasileiro, que incluem políticas de habitação, de turismo rural, valorização das amenidades, de regularização das relações trabalhistas e de urbanização do rural (serviços, infraestrutura e planejamento), entre outras.

Schneider corrobora, assim, com outros autores ${ }^{5}$ que incluem nas demandas e políticas de desenvolvimento para o novo rural e o rurubano brasileiro, a questão habitacional.

Em âmbito local, há diversos estudos que tratam da condição de microrregiões produtivas, culturais ou econômicas que têm buscado a manutenção de suas atividades sem abandonar as localidades. Das possibilidades de rendas alternativas para a agricultura familiar 
na região da Quarta Colônia, no Rio Grande do Sul (WINCK; ZONIN; NUNES DA SILVA, 2014), à proposta de multifuncionalidade da agricultura e manejo de recursos naturais no semiárido nordestino (SABOURIN, 2008), muitas são as perspectivas.

Em Santa Catarina, Mior e outros (2014, p. 21) explicam que "[...] os agricultores familiares buscam formas de ampliar as suas possibilidades de reprodução social no espaço rural, entre as quais estão a constituição de empreendimentos de agregação de valor e as redes de cooperação, acompanhados de novos tipos de posicionamentos nos mercados". E para melhor compreender essas questões no extremo sul do Estado e discutir os resultados, tem-se o estudo de Estevam, Jorge e Salvaro (2014) que promoveram uma análise entre o rural e o urbano, com o intuito de apontar as características socioeconômicas contemporâneas da região.

De acordo com os autores "Se considerar que esta é uma região composta de pequenos municípios e que oficialmente toda sede é considerada urbana, observa-se uma urbanização 'mascarada' pelos critérios em vigor no país." (ESTEVAM; JORGE; SALVARO, 2014, p. 43). Tal máscara esconde a realidade, uma vez que "[...] a Região da AMESC se caracteriza por ter sua economia baseada na agropecuária, são compostos por pequenas propriedades rurais e as famílias utilizam a força de trabalho familiar." (ESTEVAM; JORGE; SALVARO, 2014, p. 47). Talvez isto ocorra porque muitas vezes se confunde com o rural nas pequenas cidades, pois conforme as leis dos municípios, um local, que era rural, pode se transformar em urbano de direito (por decreto), mesmo que de fato não o seja.

\subsubsection{Estudos recentes das políticas públicas e habitação no meio} rural

Nesta subseção foram compilados estudos que correlacionam políticas públicas, habitação e meio rural no âmbito do objeto estudo (Incluindo políticas como o Programa Nacional de Habitação Rural - PNHR e o Programa Minha Casa Minha Vida Rural - PMCMVR). Optou-se pela apresentação dos mesmos na forma de quadro-síntese, considerando que também foram referenciais de apoio e comparação na análise dos resultados. 
POLÍTICAS SOCIAIS HABITACIONAIS RURAIS NO SUL DE SANTA CATARINA

Quadro 1 - Síntese de trabalhos que abordam a questão habitacional, as ações, agentes e políticas públicas e sociais

\begin{tabular}{|c|c|c|c|}
\hline Autor(es) & Publicação & Ano & Tema/objeto \\
\hline SORDI & $\begin{array}{l}\text { Repositório } \\
\text { Unochapecó }\end{array}$ & 2006 & $\begin{array}{l}\text { Habitação rural: o sentido da nova moradia para os } \\
\text { agricultores familiares do oeste catarinense - analisa } \\
\text { as mudanças que a nova moradia, seja ela reformada } \\
\text { ou construída, gera na vida dos agricultores da } \\
\text { região Oeste Catarinense, atendidos por programas } \\
\text { habitacionais }\end{array}$ \\
\hline MUNARINI & $\begin{array}{l}\text { Repositório } \\
\text { Unochapecó }\end{array}$ & 2009 & $\begin{array}{l}\text { A política de habitação rural brasileira e o } \\
\text { desenvolvimento da agricultura familiar no oeste } \\
\text { catarinense }\end{array}$ \\
\hline $\begin{array}{l}\text { ROVER E } \\
\text { MUNARINI }\end{array}$ & $\begin{array}{l}\text { Revista } \\
\text { Katálysis }\end{array}$ & 2010 & $\begin{array}{l}\text { A política de habitação rural e o desenvolvimento da } \\
\text { agricultura familiar - Contribuição do PNHR para o } \\
\text { desenvolvimento de territórios rurais. }\end{array}$ \\
\hline MARRA & CONPEDI & 2010 & $\begin{array}{l}\text { Políticas públicas de habitação e a efetivação do } \\
\text { direito social e fundamental }\end{array}$ \\
\hline ALMEIDA & $\begin{array}{l}\text { Repositório } \\
\text { UFBA }\end{array}$ & 2011 & $\begin{array}{l}\text { Desigualdade e políticas públicas de habitação no } \\
\text { Brasil }\end{array}$ \\
\hline $\begin{array}{l}\text { FAGUNDES } \\
\text { et al. }\end{array}$ & $\begin{array}{l}\text { Revista } \\
\text { Colóquio }\end{array}$ & 2013 & $\begin{array}{l}\text { Análise das metas do PNHR no contexto nacional - O } \\
\text { estudo apresenta uma síntese dos dados alcançados } \\
\text { pelo Programa em cada região do Brasil }\end{array}$ \\
\hline
\end{tabular}

Fonte: Elaborado pelos autores.

Por fim, cabe mencionar um trecho da exposição sobre habitação social, proferida por Vieira (2015) onde ele explica que a mesma se destina à faixa de renda da população que necessita de um subsídio (complementação) de valores não suportados pelos mutuários. A habitação social se insere, pois, como peça fundamental para o desenvolvimento e para a condição de conquista do direito à cidadania, não se restringindo apenas ao objeto casa ou unidade habitacional.

Essa assertiva vai ao encontro não só do tema deste estudo, mas também de um conjunto de ações e políticas que precisam dar suporte ao desenvolvimento de atividades rurais (agropecuárias) e não rurais e à qualidade de vida da população que vive nesse ambiente. 


\section{PROCEDIMENTOS METODOLÓGICOS}

A realização da pesquisa, articulando a temática e objeto de estudo aqui adotados, requereu abordagem qualitativa interdisciplinar, ainda que a natureza e procedimentos possam ser considerados tradicionais. Com relação à natureza, a pesquisa se caracterizou como aplicada que "[...] tem como objetivo investigar, comprovar ou rejeitar hipóteses sugeridas pelos modelos teóricos, a fim de avançar para além das reflexões teóricas e estudos básicos/puros realizados pelos pesquisadores." (RODRIGUES, 2007, p. 3). Esta condição se deu por meio da aplicação dos estudos teóricos e prévios para a compreensão da implementação das políticas sociais habitacionais na microrregião escolhida (GONÇALVES; GIANEZINI, 2016; GONÇALVES; GIANEZINI; ESTEVAM, 2015a, 2015b).

Tendo em vista o objetivo proposto, foi realizada uma pesquisa exploratória e descritiva. Os procedimentos metodológicos constituíram-se em uma tríade: Pesquisa bibliográfica, levantamento documental e pesquisa de campo (observação). O levantamento documental incidiu sobre publicações do Instituo Brasileiro de Geografia e Estatística (IBGE), Associação dos Municípios do Extremo Sul Catarinense (AMESC), Ministério das Cidades (MCID), Caixa Econômica Federal (CEF) e, em especial, junto ao Sindicato dos Trabalhadores Rurais de Turvo e Ermo (STRTE). Em concomitância, foi realizada pesquisa de campo com a técnica de observação, pelo fato de que no decorrer da mesma é possível registrar dados visíveis e com relevância específica. Os registros cursivos e anotações do diário podem contemplar um check list a ser verificado, palavras-chave e códigos que emergem de pesquisa, podendo ser transcritos/ traduzidos posteriormente. (DANNA; MATOS, 2011).

Esse momento de coleta de dados foi significativo para a obtenção dos resultados, uma vez que a técnica de observação utilizada é caracterizada como observação não-estruturada ou assistemática, também denominada espontânea, informal, simples, livre, ocasional, acidental e não planificada, onde os pesquisadores, neste caso, são espectadores e podem recolher e registrar os fatos da realidade sem utilizar meios técnicos especiais ou precisar fazer perguntas diretas. (MARCONI; LAKATOS 2008). A observação foi efetuada no tempo atual e vida real (meses de novembro e dezembro de 2015 e janeiro de 2016), com o registro feito in loco. 
Para contemplar o universo do estudo e amostra, tomou-se por base as considerações de Gerhardt (2009), que sugere recortar o campo da análise empírica num espaço geográfico e social, bem como num espaço de tempo. Conforme o caso, o pesquisador poderá estudar a população total, ou uma amostra que represente ou ilustre essa população.

A pesquisa partiu então de uma delimitação inicial, que abarcava a AMESC, criada em 1979 e atualmente composta por 15 cidades. A AMESC busca fortalecer o extremo sul do estado, um ambiente essencialmente rural, com predomínio de pequenas propriedades e significativa presença da agricultura familiar, que tem recebido apoio de políticas e agentes locais, como os sindicatos de trabalhadores rurais.

Por conseguinte, após levantamento preliminar de informações, constatou-se a relevância deste apoio, delimitando-se, assim, o universo de estudo às experiências de dois dos municípios da AMESC com maior incidência de ações e políticas habitacionais rurais, que são Turvo e Ermo (Figura 2).

Figura 2 - Extremo sul de Santa Catarina, 2016

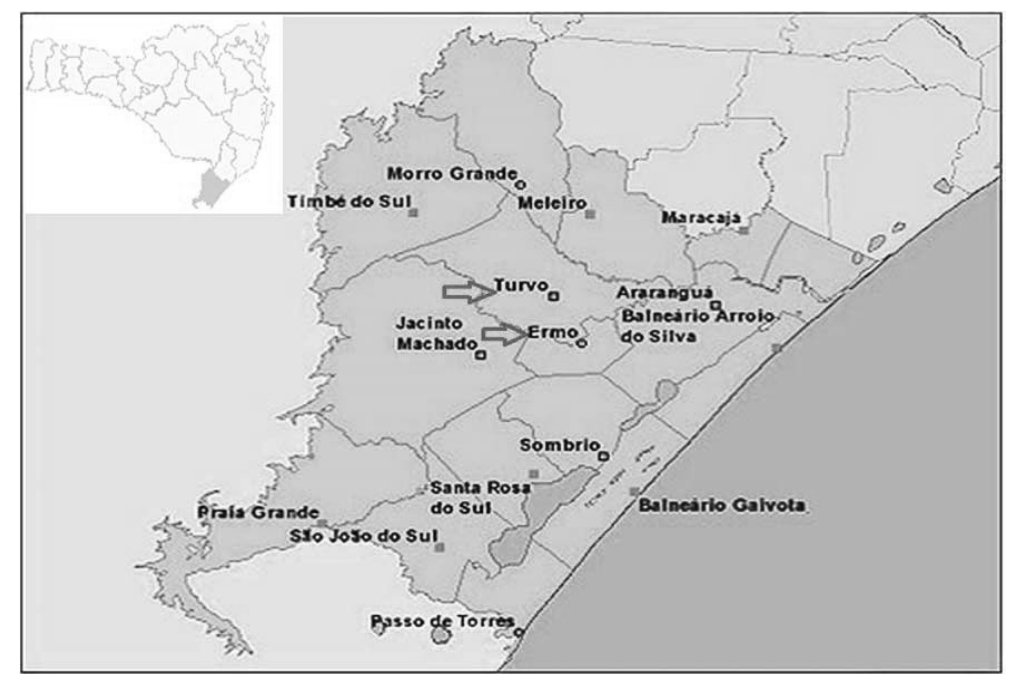

Fonte: ASSOCIAÇÃO DOS MUNICÍPIOS DO EXTREMO SUL CATARINENSE. Site Institucional: a história da Amesc. Araranguá, SC, 2016. Disponível em: <http://www.amesc.com.br/municipios/ index.php>. Acesso em: 5 fev. 2015. 
A observação foi a não participação do pesquisador, que observa, mas não está no grupo observado; presencia os fatos, mas não se integra ao grupo, tornando-se, assim, um espectador. Para Marconi e Lakatos (2008, p. 78) nesse tipo de observação,

[...] o pesquisador tem contato com a comunidade, grupo ou realidade estuda, mas sem integrar-se a ela. Presencia o fato, mas não participa dele; não se deixa envolver pelas situações; faz mais papel de espectador. Isso, porém, não quer dizer que a observação não seja consciente, dirigida, ordenada para um fim determinado.

E foi justamente essa objetividade da observação que permitiu uma percepção própria dos principais elementos que compõem a temática deste estudo e a elaboração de um esquema ilustrativo da dinâmica de pesquisa (Figura 3) que auxilia a compreender e analisar os resultados.

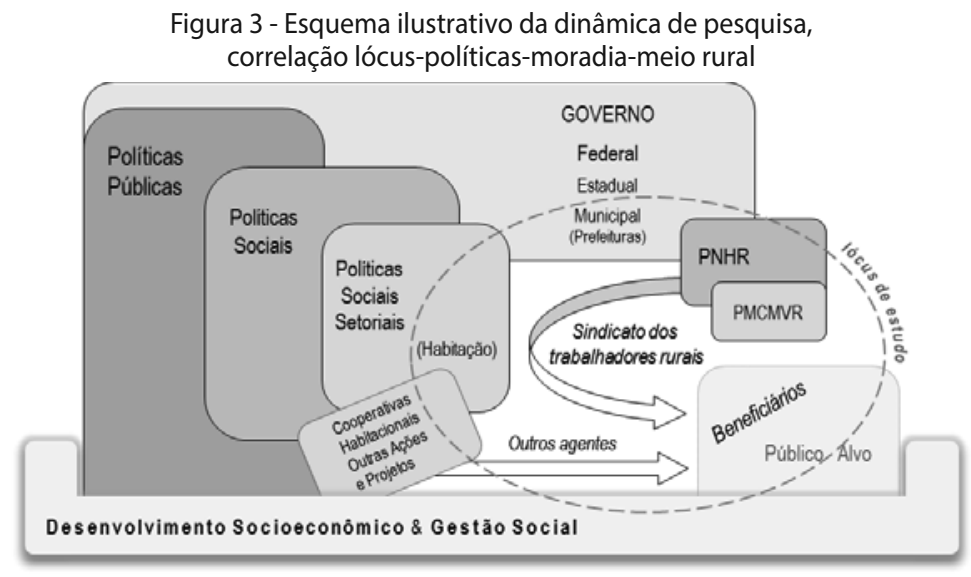

Fonte: Elaborada pelos autores.

Esse esquema denota a complexidade do tema e a necessidade de uma abordagem interdisciplinar para seu estudo. Por isso, procurou-se utilizar referenciais e elementos das áreas da Economia (desenvolvimento), Direito (legislação e direitos fundamentais), Administração Pública (gestão social), Sociologia (políticas sociais) e Arquitetura (planejamento habitacional). Consorciadas, estas áreas contribuíram na observação e compreensão do objeto estudado, e na descrição dos resultados apresentados na seção a seguir. 


\section{RESULTADOS E DISCUSSÃO}

O levantamento documental e a pesquisa de campo demonstram que, no caso específico de Turvo e Ermo, não há registros de muitas experiências habitacionais para além das iniciativas dos próprios produtores e trabalhadores rurais.

Historicamente, desde o estabelecimento dos imigrantes que colonizaram a região, as residências eram construídas pelas famílias e amigos e recebiam melhorias ao longo do tempo. Há exemplares de casas originais daquele período que ainda estão de pé, e algumas, mesmo que em condições precárias, servem de residência até hoje ${ }^{6}$.

Nos últimos anos, constatou-se que houve ações que foram propostas por cooperativas habitacionais e programas de empresas de marketing ambiental de fora da região, oferecendo serviços que, na verdade, se aproximavam de práticas de empresas privadas. Contudo, foi observado que essas experiências não surtiram os resultados desejados, havendo somente o registro de 2 (duas) unidades construídas nessa modalidade desde o ano de 2012.

Concomitantemente a essas ações, surgia nesse cenário, uma iniciativa que, em conformidade ao entendimento do referencial estudado (KLIKSBERG, 1994; SILVA JR.; GONÇALVES; CALOU, 2008; TENÓRIO, 2008; CANÇADO, 2011) contribuiu com a Gestão do Desenvolvimento Social local no que diz respeito ao acesso às políticas habitacionais para a população rural. Trata-se do apoio do STRTE, representante local da Federação dos Trabalhadores na Agricultura do Estado de Santa Catarina (FETAESC) e da Confederação Nacional dos Trabalhadores na Agricultura (CONTAG).

No âmbito do PNHR, foram coletadas informações junto ao setor Técnico de Habitação e Projetos da FETAESC, enquanto Entidade Organizadora (EO) para mais de 200 municípios catarinenses. Tais informações abarcam os anos de 2009 a 2015 (com contratações entre 2012 e 2014, etapa 2) e são referentes apenas ao Grupo 1 (G1). Foram, portanto, 718 em 2012, 1.275 em 2013, 1.948 em 2014 e $118 \mathrm{em} 2015$, totalizando mais de 4.000 Unidades, somando-se as unidades construídas e reformadas.

Apesar de a FETAESC apoiar o STRTE, cabe mencionar que os dados supracitados não incluem as unidades construídas ou reformadas em Turvo e Ermo, pois nestes casos se trata de EO diferente. Por isso, ao orientar as famílias no atendimento dos requisitos do 
PNHR e acompanhar as obras das unidades habitacionais, o sindicato local tornou-se peça chave nesse processo.

\subsection{A importância do Sindicato Rural Local no processo de implementação das políticas}

Os sindicatos são importantes tanto para levar a informação, quanto à execução e auxílio aos trabalhadores, agindo como intermediário em alguns casos, como foi observado no STRTE. Além dos serviços geralmente disponibilizados aos sindicalizados ${ }^{7}$, o Sindicato local teve papel relevante para a implementação de políticas e construção e reforma das habitações no meio rural.

Cabe mencionar que, de acordo com as modalidades do PNHR, o sindicato utiliza como base o G1 (até $\left.60 \mathrm{~m}^{2}\right)^{8}$, que é uma casa nova no valor de $\mathrm{R} \$ 28.500,00$ e a reforma de $\mathrm{R} \$ 17.200,00$, onde se devolve $4 \%$ para a CEF em 4 anos ( $1 \%$ ao ano). Já foram construídas ou reformadas, com a ajuda do sindicato, mais de 150 unidades habitacionais do G1, sendo que as 24 primeiras famílias contempladas foram também ajudadas pela $\mathrm{COHAB} / \mathrm{SC}$. Pelo PNHR, no período estudado, foram 75 unidades novas e 40 reformadas 9 .

Na percepção dos beneficiários, o apoio do sindicato foi e continua sendo importante, pois eles confiam no mesmo, pela proximidade, ainda mais, depois das experiências com agentes de fora da região. Além disso, foi com o apoio do sindicato que os pequenos produtores e trabalhadores rurais perceberam que era mais fácil construir ou reformar suas casas, pois o sindicato é um ente que congregou esses agentes ${ }^{10}$.

Nesse ponto, recorda-se dos estudos de Tenório (2008), que explica que no processo de Gestão Social há uma promessa de consenso racional, onde a relação não se dá entre o indivíduo e a sua percepção de mundo, mas sim por meio de um acordo alcançado com discussão crítica e apreciação intersubjetiva, o que incluiria o processo estudado no âmbito da Gestão Social.

\subsection{Resultados da observação in loco}

Nesta seção são apresentadas as unidades habitacionais que foram construídas ou reformadas pelo PNHR. Dentre as moradias visitadas, foram escolhidos 5 (cinco) exemplos. 
O primeiro deles é de uma unidade habitacional, construída na localidade de Morro Chato, no distrito de Vila Rezin, munícipio de Turvo (Figura 4). Após observação e contato com o beneficiário, foi constatado que o mesmo soube do plano por outros moradores da localidade e achou fácil o acesso ao mesmo. A casa conta com dois quartos, sala e cozinha conjugadas e um banheiro. Os custos foram divididos entre o grupo ${ }^{11}$ do qual ele participou, e o mesmo pagará a casa em 4 anos $(1 \%$ ao ano). A renda da família é proveniente de plantações de arroz, milho, eucalipto.

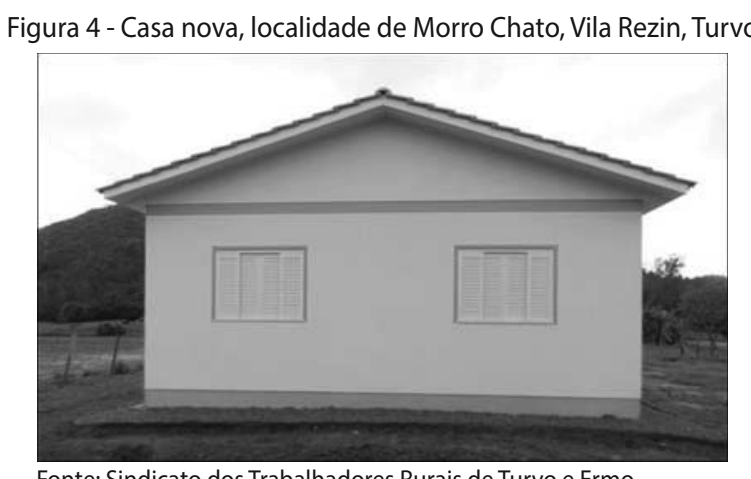

Fonte: Sindicato dos Trabalhadores Rurais de Turvo e Ermo.

A segunda unidade habitacional visitada foi reformada (Figura 5), também, na localidade estrada geral, Morro Chato (Turvo). Constatou-se que a intervenção em uma casa reformada se diferencia da casa nova, não só nos valores, mas também porque possui projeto individual, sendo que esse projeto precisa atender à necessidade da família.

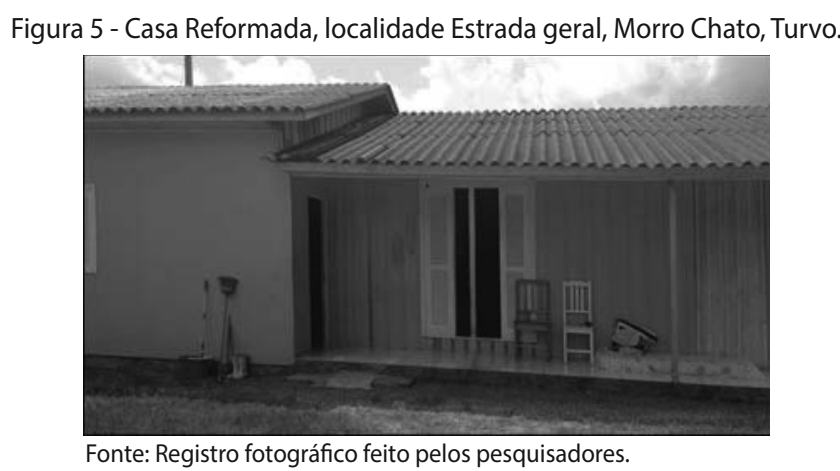


Nesse caso, a beneficiada (aposentada rural) foi assinar a documentação para um sobrinho candidatar-se a uma casa nova. Mas na ocasião, houve uma importante intervenção que demonstra a relevância do papel do STRTE. Isso porque o sindicato identificou a necessidade e a orientou, incentivando-a, além de representar o sobrinho, a reformar sua própria residência. Foram então feitos cozinha, quarto e banheiro novos, anexos à casa existente.

O terceiro exemplo é o de uma Unidade Habitacional nova, na Localidade Estrada Geral (Ermo). A casa foi construída em um grupo de aproximadamente 30 famílias; o que se destacou, foi que além dos 2 quartos, cozinha e sala conjugadas e 1 banheiro, a família já está aumentando e fazendo uma garagem, área de serviço e uma área livre (Figura 6). O projeto já prevê que se possa expandir a área construída depois da casa pronta. Os beneficiários tiveram conhecimento do plano por familiares, e sua renda vem do trabalho na lavoura. Esse é um típico caso no qual há uma diferença perceptível com relação às moradias e políticas urbanas.

Salvo algumas exceções, as moradias populares urbanas não possuem espaço/estrutura para uma ampliação adequada, e quando há ampliações, as mesmas são conhecidas como puxadinhos, construídos de forma improvisada. Além disso, cabe mencionar aqui outra constatação. A antiga moradia estava em condições precárias e não permitia reforma, mas foi mantida como depósito, paiol (Figura $7)$.

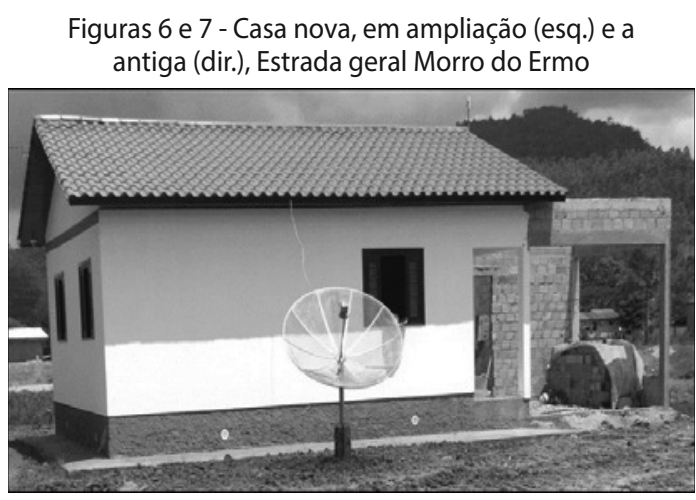




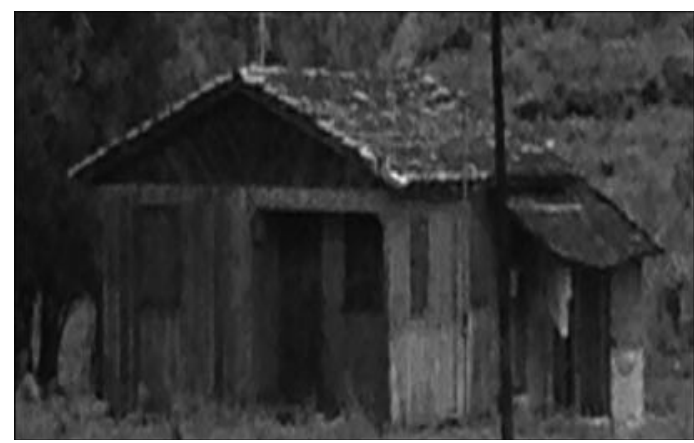

Fonte: Registro fotográfico feito pelos pesquisadores.

A quarta visita de observação foi em uma unidade habitacional reformada (Figura 8) na Localidade de Vila Progresso, no município de Turvo. Este também foi um típico exemplo no qual ficou constatado que o sindicado instruiu e apoiou o casal (aposentados rurais) para a reforma. Foi reformado o forro, construído um banheiro novo, feita a pintura, telhado, construída área de serviço e feita a instalação elétrica nova (Figura 9).

Figura 8 e 9 - Casa Reformada, Localidade de Vila Progresso, Turvo.

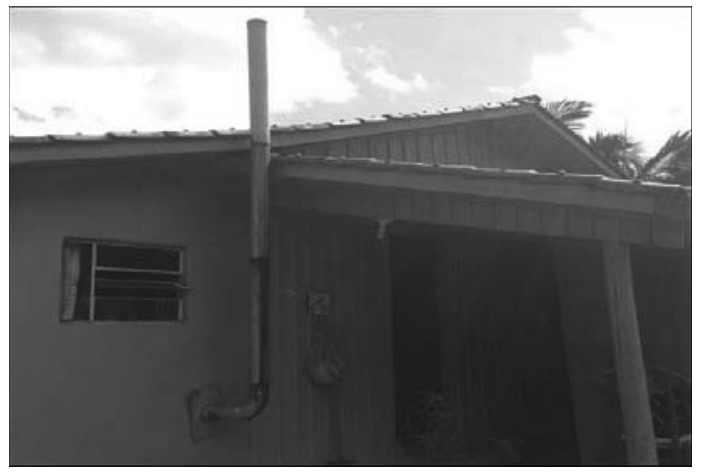




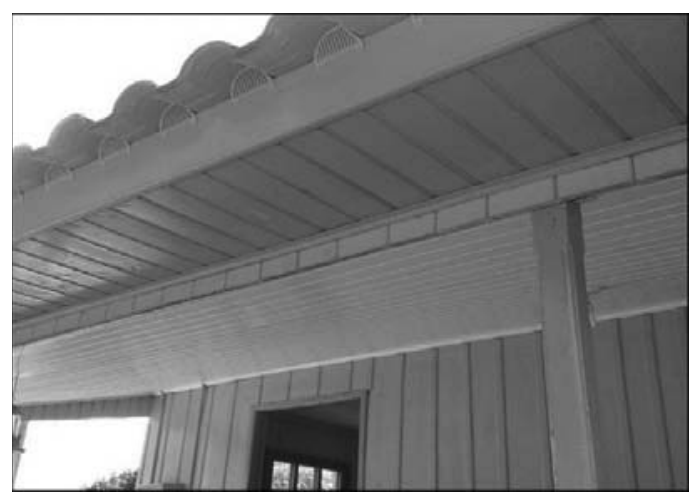

Fonte: Registro fotográfico feito pelos pesquisadores.

O quinto e último exemplo de unidade habitacional observado, foi uma casa nova, construída na Localidade Rodeio de Areia (Turvo). Observou-se que foi construída a casa padrão (2 quartos, cozinha e sala conjugada, 1 banheiro); o beneficiário mora e trabalha na localidade. Este caso é semelhante ao da Estrada Geral, onde a antiga moradia estava em condições precárias e de acordo com a avaliação da CEF, não permitia reforma (Figura 11). Tal caso vai ao encontro das características e ações apontadas por Fagundes e outros (2013) ao analisarem as metas do PNHR no contexto nacional.

Figuras 10 e 11 - Casa nova (esq.) e a antiga (dir.), Localidade Rodeio de Areia, Turvo

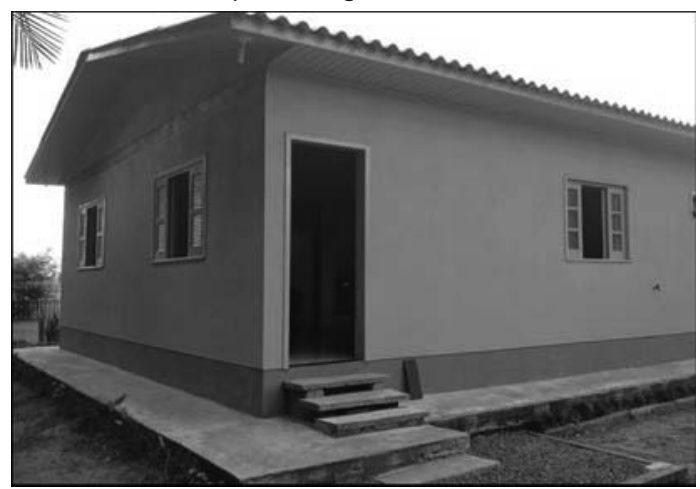




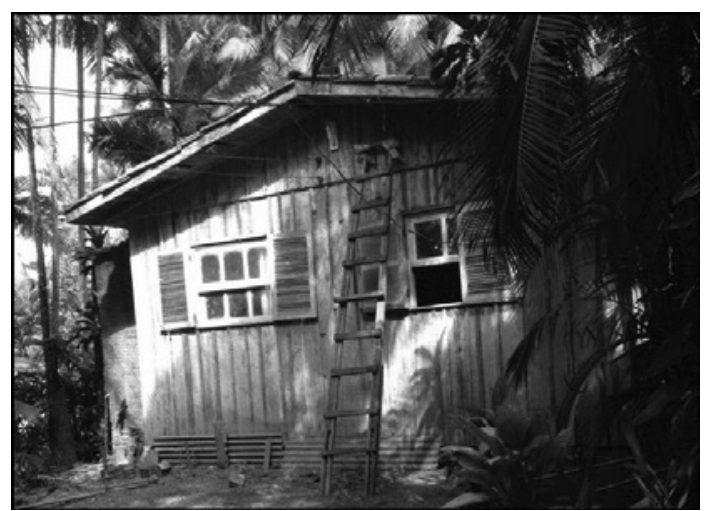

Fonte: Registro fotográfico feito pelos pesquisadores.

Após a apresentação de alguns dos exemplos das unidades observadas, cabe mencionar, ao final desta seção, que não se pretendeu, ao incluir as imagens, fazer uma comparação simplista do tipo antes e depois ${ }^{12}$. Nessa questão, podem-se mencionar políticas como o Programa Nacional de Fortalecimento da Agricultura Familiar (PRONAF) destinado "[...] a estimular a geração de renda e melhorar o uso da mão de obra familiar por meio do financiamento de atividades de serviços rurais agropecuários e não agropecuários desenvolvidos em estabelecimento rural." (BANCO CENTRAL DO BRAISL, [20--?], grifo nosso). Esse tipo de programa é importante, mas cabe ressalvar que são ofertados mais recursos e possibilidades para o armazenamento de grãos e abrigo de animais, do que para a habitação do próprio trabalhador rural.

\subsection{Discussão}

Em observância ao referencial conceitual das políticas públicas, sociais e ou setoriais, que apontam que as mesmas (surgidas inicialmente na Europa) foram provenientes de um modo de democratização social do capital, resultado das demandas dos assalariados e com capacidade de lhes conferir uma expressão política coletiva (ESPING-ANDERSEN, 1985), entende-se que há algumas semelhanças possíveis junto ao objeto aqui estudado.

Isso porque muitos dos integrantes das famílias beneficiadas são também trabalhadores assalariados em empresas da região e, 
apesar do emprego fabril, residem no campo e buscam uma expressão coletiva desta sua condição rurubana.

Nesse caso, a caracterização de Graziano da Silva (1999) e Schneider (2010) foi perfeita para o lócus desta pesquisa, uma vez que há implementação de políticas que vão ao encontro da habitação para o desenvolvimento rural. E por serem focadas na habitação, também se constatou o caráter de política social, uma vez que está voltada especificamente para determinada situação. (REIS, 1989).

Durante a pesquisa de campo, foram visitadas casas novas e reformadas, nas quais se constatou-se que a maioria dos beneficiários ainda trabalha em atividades agropecuárias na roça ou são aposentados rurais, que desejam que seus filhos possam continuar residindo próximo a eles, mesmo que escolham outra atividade na cidade.

Os programas contribuem não só para a moradia, mas também para a manutenção de atividades agropecuárias tradicionais no extremo sul de Santa Catarina (além de outras atividades não rurais) em um panorama que se aproxima do que foi preconizado por Graziano e reiterado por Schneider ainda na década passada.

Muitos dos beneficiados poderiam ter se mudado para o meio urbano e, com isso, descontinuado sua produção; considerando que são pequenos agricultores, dedicados a culturas específicas, a região poderia também perder em diversidade.

Portanto, ainda que não se possa generalizar, pois este não era um dos objetivos deste estudo, há que se considerar que tais ações implementadas são tão ou mais importantes, que aquelas destinadas ao meio urbano. Tal consideração é respaldada pelo referencial que trata do desenvolvimento rural, em especial, após o advento de políticas especificas para a agricultura familiar no Brasil.

Em contrapartida, é importante mencionar que boa parte deste referencial toma por base as condições significativamente heterogêneas do Brasil. Isso significa dizer que, como já havia apontado Almeida (2011) no estudo acerca da desigualdade e políticas públicas de habitação no Brasil, as condições sócio-históricas e estruturais de outras regiões como o semiárido nordestino, o vale do Jequitinhonha, a campanha gaúcha ou pantanal Mato-Grossense possuem peculiaridades que não permitem paralelos, incluindo aqui os municípios do Extremo Sul catarinense. 
E, por isso, para dar conta dessa diversidade, que se observou a crescente literatura que trata da condição da agricultura familiar no Sul do Brasil associada inclusive à questão habitacional, com destaque para os estudos de Sordi (2006), Munarini (2009) e Rover e Munarini (2010).

Acredita-se, portanto, que é necessária a consolidação de estudos que articulem cada vez mais esta literatura com outras - que tratam de políticas sociais setoriais complementares (como saneamento, saúde, educação no campo e outras) ou que apontam a habitação como o ponto central desta articulação (SOUZA SANTOS, 2002) - promovendo assim, avanços na compreensão das necessidades do desenvolvimento rural no Brasil contemporâneo.

No caso das políticas habitacionais, como observado, é preciso continuidade das ações para que os trabalhadores e pequenos produtores rurais (e demais familiares que vivem na mesma residência com eles) possam dedicar seu tempo às suas atividades e não às reformas e consertos de uma casa velha que só dá traba1ho. ${ }^{13}$

Constatou-se, também, que nos últimos anos houve uma espécie de resgate - representado em especial pela implementação do PNHR - da dívida com esta população rural. Isto porque se trata de uma política que foi além das políticas governamentais ou ações de habitação social, com origem histórica no meio urbano, como foi a do BNH, estudada por Bonduki (1994) e Azevedo (1988).

A experiência das ações habitacionais no meio rural dos municípios estudados, e em especial da implementação do PNHR por meio de um sindicato (como Entidade Organizadora - EO), pode ser considerada uma política pública social de fato, como definida por Souza (2006), enquanto tradução de propósitos de governos democráticos em programas e ações que produzem mudanças no mundo real.

\section{CONCLUSÃO}

O estudo teve como objetivo analisar as políticas públicas sociais habitacionais (com ênfase na gestão social e no desenvolvimento rural), implementadas no sul catarinense. Para atendê-lo, buscou-se identificar políticas para a habitação de interesse social no Brasil. Após pesquisa bibliográfica o assunto foi apresentado na 
seção de referencial e, mesmo que não tenha uma relação direta com o objeto estudado na discussão (pois a maioria trata do ambiente urbano), foi importante para compreensão do contexto e condição de surgimento das políticas e ações na atualidade.

Além disso, foram descritos os projetos de habitação popular no meio rural nos municípios de Turvo e Ermo (iniciativas, cooperativas e programas) com ênfase no PNHR e seus requisitos. Para tal, procedeu-se ao levantamento documental e pesquisa de campo. Diante das informações dos agentes, observou-se, por exemplo, que houve outras iniciativas que não deram certo, e que os requisitos do PNHR foram decisivos para serem contemplados.

Por conseguinte, foram observados os resultados e conhecidas as características, por meio de amostra representativa, em contato com agentes sociais locais (apoiadores e beneficiários), com destaque para o convênio do sindicato dos trabalhadores rurais com a CEF no âmbito do PNHR.

Ficou claro o trabalho conjunto da CEF com o STRTE e seus associados para atendimento à implementação do PNHR, em especial, incentivando e suscitando a utilização do mesmo. É perceptível a importância, pois é mais uma obra que oferece maior conforto à vida no campo, possibilitando que os trabalhadores optem por morar ali e não mudem para as áreas urbanas.

Assim, acredita-se então que uma possível contribuição deste estudo reside não só no fato de apresentar uma abordagem interdisciplinar, mas também em promover uma discussão acerca das políticas sociais habitacionais rurais no extremo sul de Santa Catarina. Em âmbito regional, tal discussão pode subsidiar a compreensão do mosaico da política nacional de habitação rural, apresentando novas possibilidades para prefeituras, sindicatos, cooperativas, associações e outros agentes, que por meio da implementação de ações e políticas, possibilitem que as pessoas continuem morando no campo e induzindo o desenvolvimento socioeconômico regional.

Por fim, há que se reconhecer, contudo, que a natureza do estudo e técnica de pesquisa de observação teve fatores limitantes, como as raras fontes documentais sobre outras ações habitacionais não institucionais; os ainda poucos estudos encontrados sobre o PNHR e, principalmente, sobre essa política no extremo sul Cata- 
rinense; o pequeno recorte amostral, restrito a dois municípios; e a complexidade da própria abordagem interdisciplinar.

Tendo em vista essas e outras limitações, mas sabendo que as mesmas podem ser superadas, entende-se que seja possível a continuação da pesquisa nesta temática (políticas sociais no meio rural), que pode ser aplicada a este ambiente ainda pouco abordado por estudos interdisciplinares acerca das políticas sociais setoriais, que é o Sul de Santa Catarina.

\section{REFERÊNCIAS}

ABRAMOVAY, R. O futuro das regiões rurais. Porto Alegre: UFRGS, 2003.

ABRANCHES, S. The politics of social welfare development in Latin America. Rio de Janeiro: IUPERJ, 1982. (Série Estudos).

ABREU, A. C. Crise do capital e orçamento público da habitação social no Brasil. Revista Políticas Públicas, São Luís, v. 20, n. 1, p. 289-306, jan./jun. 2016.

ALMEIDA, I. F. G. de. Desigualdade e políticas públicas de habitação no Brasil. 2011. 158 f. Dissertação (Mestrado em Ciências Econômicas) - Universidade Federal da Bahia, Salvador, 2011. Disponível em: < https://repositorio.ufba.br/ri/ bitstream/ri/ 8907/1/Isaura\%2520Almeida.pdf $>$. Acesso em: 10 abr. 2015.

ASSOCIAÇÃO DOS MUNICÍPIOS DO EXTREMO SUL CATARINENSE. Site Institucional: a história da Amesc. Araranguá, SC, 2016. Disponível em: <http://www.amesc.com.br/ municipios/index.php>. Acesso em: 5 fev. 2015.

AZEVEDO, S. Vinte e dois anos de política habitacional popular. (1964-86): criação, trajetória e extinção do BNH. Revista de Administração Pública, Rio de Janeiro, v. 22, n. 4, p. 107-119, out-dez. 1988.

BACON, F. The essays or counsels civil and moral. London: J.M. Dent \& Co; New York: E.P. Dutton \& Co, 1906. Disponível em: $<$ https://archive.org/details/ essayescounsel00bacoiala>. Acesso: 16 maio 2016.

BANCO CENTRAL DO BRASIL.. FAQ - Programa Nacional de Fortalecimento da Agricultura Familiar - Pronaf. Brasília, 
DF, [20--?]. Disponível em: <http://www.bcb.gov.br/pre/bc_atende/ port/PRONAF.asp\#1>Acesso em: 2 mar. 2016.

BONDUKI, N. G. Habitat: As práticas bem-sucedidas em habitação, meio ambiente e gestão urbana nas cidades brasileira. São Paulo: Studio Nobel, 1997.

BRESCIANI, M. S. M. Londres e Paris no século XIX: o espetáculo da pobreza. 8. ed. São Paulo, 1994.

CANÇADO, A. C. et al. Os desafios da formação em Gestão Social. Palmas: Provisão, 2008.

. Fundamentos teóricos da gestão social. 2011. $246 \mathrm{f}$. Tese (Doutorado) - Universidade Federal de Lavras, Lavras, 2011.

CARDOSO, A. L.; ARAGÃO, T. A.; ARAUJO, F. S. Habitação de Interesse Social: Política ou Mercado? Reflexos sobre a Construção do Espaço Metropolitano. In: ENCONTRO NACIONAL DA ANPUR, 14., 2011, Rio de Janeiro. Anais... Rio de Janeiro: ANPUR, 2011. Disponível em: $<$ http://www. observatoriodasmetropoles .net/download/adauto_cardoso.pdf $>$. Acesso em: 6 abr. 2015.

COSTA, C. E. S. Habitação rural: uma proposta de racionalização pela autoconstrução. Seropédica: Edur (UFRRJ), 1995.

DANNA, M. F.; MATOS, M. A. Aprendendo a observar. 2. ed. São Paulo: Edicon, 2011.

DENALDI, R.; LEITÃO, K.; AKAISHI, A. O recente processo de elaboração de planos locais de habitação de interesse social no Brasil: limitações e perspectivas. In: ENCONTRO NACIONAL DA ANPUR, 14., 2011, Rio de Janeiro. Anais... Rio de Janeiro: ANPUR, maio 2011. Disponível em: $<$ http:// unuhospedagem.com. br/revista/rbeur/index.php/anais/article/ view/2652>. Acesso em: 6 abr. 2015.

DRAIBE, S. M. Repensando a Política Social: dos anos 80 ao início dos 90. In: SOLA, L.; PAULANI, L. M. (Org.). São Paulo: USP, 1999. p. 201-221.

ENGELS, F. The housing question. New York: International publishers, 1935.

ESPING-ANDERSEN, G. Power and distributional regimes. Politics \& Society, [S. 1.], v. 14. n. 2, p. 223-256, 1985. 
ESTEVAM, D. de O.; JORGE, T. P.; SALVARO, G. I. J. Características socioeconômicas da Região do Extremo Sul Catarinense: uma análise entre o rural e o urbano. Revista NECAT, Florianópolis, SC, v. 3, p. 31-56, 2014.

FAGUNDES, J. R. et al. Análise das metas do Programa Nacional de Habitação Rural - PNHR no contexto nacional. Colóquio: Revista do Desenvolvimento Regional, Taquara, RS, v. 10, n. 2, 2013. Disponível em: $<$ http://seer.faccat.br/index.php/ coloquio/ article/view/29/pdf_7>. Acesso em: 5 maio 2015.

FURTADO, C. Introdução ao desenvolvimento: enfoque histórico-estrutural. Rio de Janeiro: Paz e Terra, 2000.

GERHARDT, T. E. A construção da pesquisa. In: SILVEIRA, D. T. S. (Orgs). Métodos de pesquisa. Porto Allegre: Ed. da UFGRS, 2009. p. 43-64.

GIANEZINI, K.; BARRETTO, A. M. L.; VIEIRA, R. de S. Políticas públicas e seu processo de criação: apontamentos introdutórios. In: COSTA, M. M.; RODRIGUES, H. T. (Org.). Direito e Políticas Públicas X. Curitiba: Multideia, 2015. p.161172.

GONÇALVES, J. P.; GIANEZINI, M. Implementação de políticas habitacionais no meio rural: a experiência dos municípios catarinenses de Turvo e Ermo. In: X ENCONTRO DE ECONOMIA CATARINENSE, 10., 2016, Blumenau. Anais... Blumenau: FURB/APEC, 2016. v. 1. p. 60-61. ; _. Políticas socioambientais na região sul de Santa Catarina. In: SEMINÁRIO DE CIÊNCIAS SOCIAIS APLICADAS, 4., Criciúma, 2014. Anais... Criciúma: UNESC, 2014. v. 4. p. 1495. Disponível em:<http://periodicos.unesc.net/ index.php/seminariocsa/article/view/1495>. Acesso em: 20 mar. 2015.

; _ ; ESTEVAM, D. O. Desenvolvimento e ações habitacionais rurais no extremo sul de Santa Catarina. In: SIMPÓSIO DE INTEGRAÇÃO CIENTÍFICA E TECNOLÓGICA DO SUL CATARINENSE, 4., 2015, Sombrio. Anais... Sombrio, 2015a. v. 1. p. 1333-1348. Disponível em: $<$ http://www.criciuma.ifsc.edu.br/sict-sul/images/Anais2015.pdf>. Acesso em: 20 mar. 2016.

Políticas sociais no meio rural: $\overrightarrow{\text { proposta }} \overline{\text { de ações para cooperativas habitacionais no extremo }}$ 
sul catarinense. In: GIANEZINI, K.; LIBARDONI, P. (Org.) Estudos contemporâneos em Ciências Jurídicas e Sociais. 1 ed. Curitiba: CRV, 2015b. p. 168-188. v. III.

GRAZIANO DA SILVA, J. O novo rural brasileiro. Campinas, SP: UNICAMP, 1999. (Coleção Pesquisas, 1).

KLIKSBERG, B. A gerência social, uma gerência diferente. In: 1994 Pobreza: uma questão inadiável. Brasília, DF: ENAP,

MARCONI, M. de A.; LAKATOS, E. M. Técnicas de Pesquisa. 7. ed. São Paulo: Atlas, 2008.

MARICATO, E. T. Brasil, cidades: alternativas para a crise urbana. 3. ed. Petrópolis: Vozes, 2001.

MARRA, N. C. Políticas públicas de habitação e a efetivação do direito social e fundamental à moradia. XIX ENCONTRO NACIONAL DO CONPEDI, 11., 2010, Fortaleza. Anais... Fortaleza: CONPEDI, 2010. Disponível em: <http://www. conpedi.org.br/manaus/arquivos/anais/fortaleza/3309.pdf $>$ Acesso em: 25 abr. 2015.

MENDRAS, H. Introduction. In: La fin des paysans: suivi d'une refléxion sur la fin des paysans vingt ans après. Arles: Actes Sud, 1984. p. 9-35. Disponível em: <http://www.irts-fc.fr:8080/Record.htm?idlist=1\&reco $\mathrm{rd}=19102229124919204019>$. Acesso em: 23 fev. 2015.

MIOR, L. C. et al. Inovações organizacionais da agricultura familiar no Sul Catarinense. In: ESTEVAM, D. de O.; MIOR, L. C. (Org.). Inovações na agricultura familiar: as cooperativas descentralizadas em Santa Catarina. Florianópolis: Insular, 2014.

MUNARINI, P. R. A política de habitação rural brasileira e o desenvolvimento da agricultura familiar no oeste catarinense. 2009. 71 f. Monografia (Curso de Agronomia) - Universidade Comunitária Regional de Chapecó, Chapecó, 2009.

PARENTE, F. J. C. Políticas Públicas e Sociedade. Revista de Ciências Sociais, Fortaleza, ano 1, n. 1, 2001. Prefácio.

POSSAMAI, C.; VITALLI, M. Habitação rural já é realidade no extremo sul de Santa Catarina. Portal SATC, [S. 1.], 2011.

REIS, E. P. Política e políticas públicas na transição democrática. In: MOURA, A. de M. (Org.). O Estado e as políticas públicas 
na transição democrática. São Paulo: Vértice/Editora Revista dos Tribunais; Recife: Fundação Joaquim Nabuco, 1989. p. 90-104.

RODRIGUES, W. C. Metodologia Científica. Paracambi: FAETEC/IST, 2007. Disponível em: $<$ http://unisc.br/portal/upload/ com_arquivo/metodologia_cientifica.pdf $>$. Acesso em: 15 mai. $201 \overline{5}$.

ROVER, O. J.; MUNARINI, P. R. A política de habitação rural e o desenvolvimento da agricultura familiar. Katálysis, Florianópolis, v. 13, n. 2, p. 260-269, 2010. Disponível em: $<$ http://www.scielo.br/pdf/rk/ v13n2/13.pdf $>$. Acesso em: 15 mai. 2015

SABOURIN, E. Multifuncionalidade da agricultura e manejo de recursos naturais: alternativas a partir do caso do semiárido brasileiro. Tempo da Ciência, São Paulo, v. 15. n. 29, p. 9-27, 2008.

SCHNEIDER, S. Situando o desenvolvimento rural no Brasil: o contexto e as questões em debate. Revista de Economia Politica, São Paulo, v. 30, n. 3, set. 2010. Disponível em: $<$ http://www.scielo.br/scielo.php?script= sci_arttext\&pid=S010131572010000300009\&lng=pt\&nrm=iso $>$. Acesso em: 20 set. 2015.

SILVA JR., J. T.; GONÇALVES, S. M. da S.; CALOU, Â. L. Avaliando Experiências de Gestão Social: os impactos do banco palmas para o desenvolvimento do território nos últimos 10 anos (1998-2007). In: ENCONTRO DA ASSOCIAÇÃO NACIONAL DE POS-GRADUAÇÃO E PESQUISA EM ADMINISTRAÇÃO, 32., 2008, Rio de Janeiro. Anais..., Rio de Janeiro: ANPAD, 2008. 1 CD ROM.

SORDI, D. G. Habitação Rural: o sentido da nova moradia para os agricultores do oeste catarinense. 2006. Trabalho de Conclusão de Curso (Graduação) - Universidade Comunitária Regional de Chapecó, Chapecó, SC, 2006. Disponível em: $<$ http://livros01.livrosgratis.com.br/ea000121.pdf $>$. Acesso em 15 mai. 2015.

SOUZA SANTOS, R. Notas metodológicas para a concepção de uma nova política social para o Brasil. Revista de Administração Pública, Rio de Janeiro, v. 36, n. 6, p. 933-957, nov./dez. 2002.

SOUZA, C. Políticas públicas: uma revisão da literatura.

Sociologias, Porto Alegre, ano 8, n. 16, p. 20-45, jul./dez. 2006. 
TENÓRIO, F. G. (Re)visitando o conceito de Gestão Social. In: SILVA JR. et al. (Org.) Gestão Social: Práticas em debate, teorias em construção. Fortaleza: Imprensa Universitária, 2008.

VIEIRA, J. L. Habitação Social (1985-2010). In: SEMANA DE CIÊNCIA E TECNOLOGIA, 6., Criciúma, SC, 2015. Palestra... Criciúma, SC: UNESC, 2015.

WANDERLEY, M. N. B. A valorização da Agricultura familiar e a reivindicação da ruralidade no Brasil. Desenvolvimento e Meio Ambiente, Curitiba, n. 2, p. 29-37, jul./dez. 2000.

WINCK, C. A.; ZONIN, V. J.; NUNES DA SILVA, T.

Agricultura familiar e rendas alternativas na região da Quarta Colônia/RS. Revista Brasileira de Gestão e Desenvolvimento Regional, Tabauté, SP, v. 10, p. 28-51, 2014.

\section{Notas:}

1 À Coordenação de Aperfeiçoamento de Pessoal de Nível Superior (CAPES), e aos Grupos de pesquisa em Estratégia, Competitividade e Desenvolvimento (GEComD) e Grupo Interdisciplinar de Pesquisa e Extensão em Desenvolvimento Socioeconômico, Agricultura Familiar e Educação do Campo (GIDAFEC) da UNESC.

2 Os autores ponderam, contudo, que nesses textos não fica claro se a condução dos projetos/programas/políticas seria democrática, participativa, descentralizada, dialógica, compartilhada ou cidadã.

3 Alguns exemplos em atividade podem ser encontrados em ONGs de habitação da ONGs Brasil. (Disponível em: $<$ http://www.ongsbrasil.com.br/default.asp? Pag=11\&TipoPesqu isa $=$ Finalidade $\&$ PalavraChave $=13>$ ).

4 Em consonância com o objeto desta pesquisa pode-se mencionar como exemplo a atuação da Cooperativa Habitacional da Agricultura Familiar (COOHAF) do Rio Grande do Sul.

5 Além de Graziano e Schneider, podem ser mencionados aqui autores como: Ricardo Abramovay (2003), principal referência dos estudos de caracterização das regiões rurais no Brasil; Maria de Nazareth Baudel Wanderley (2000), que propõe a valorização da agricultura familiar e a reivindicação da ruralidade no Brasil; e José Eli da Veiga (2007), que trata das definições de rural utilizadas pelos órgãos governamentais no Brasil, com foco na abordagem territorial.

6 Há inclusive um projeto de fotos, coordenado pelo Sr. Ivo Contessi que faz o registro regular destas habitações.

7 Atualmente (2016) há mais de 4.000 Sindicatos de Trabalhadores e Trabalhadoras Rurais (STTR) em todo o Brasil, que são responsáveis por representar os agricultores familiares. Em um STTR é possível realizar serviços como: Cadastro Ambiental Rural; Assistência jurídica; Assistência saúde (convênios); Imposto Territorial Rural (ITR); Informações sobre legislação ambiental; e Encaminhamento de benefícios Previdenciários.

8 Isto não significa que o STRTE auxilie apenas este grupo. Dede 2010 há registros de casas de pequenos produtores rurais construídas ou reformadas, dos grupos 2 e 3, pelo programa MCMVR na região (POSSAMAI; VITALI, 2011).

9 Este número pode ser considerado pequeno perante as unidades construídas ou reformadas pela FETAESC. Isto se configura em uma limitação amostral, sem possibilidade de generalização. Por outro lado, mesmo que Turvo e Ermo possuam área geografia e 


\section{POLÍTICAS SOCIAIS HABITACIONAIS RURAIS NO SUL DE SANTA CATARINA}

população pequenas, podem ser um modelo para muitos outros municípios catarinenses com o mesmo perfil.

${ }^{10}$ Em especial porque no âmbito do PNHR, os beneficiários foram organizados de forma coletiva por intermédio do STRTE que, nesse caso, é caracterizado como uma EO, onde se enquadram cooperativas, associações, sindicatos ou poder público.

${ }^{11}$ Salienta-se, pois, que o custo também tem sido menor, com apoio do Sindicato (como EO), porque são criados grupos de famílias interessadas, barateando a documentação e o processo.

12 Isto porque não se trata apenas do aspecto visual, pois como já mencionara Francis Bacon (1906, p. 133) ainda no Século XVII “As casas são construídas para que se viva nelas, não para serem olhadas".

${ }^{13}$ Mesmo que algumas das casas possam ser consideradas como patrimônio histórico não oficial, as expressões aqui usadas foram pinçadas do contato com os beneficiários, e registradas em diário de campo, durante a observação. 
